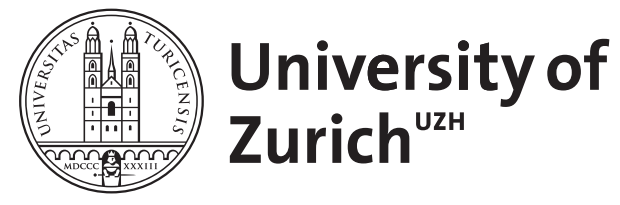

ECG monitoring after acute ischemic stroke: Does patient selection matter?

Katan, Mira ; Lubitz, Steven A

DOI: https://doi.org/10.1212/WNL.0000000000006719

Posted at the Zurich Open Repository and Archive, University of Zurich ZORA URL: https://doi.org/10.5167/uzh-166131

Journal Article

Published Version

Originally published at:

Katan, Mira; Lubitz, Steven A (2019). ECG monitoring after acute ischemic stroke: Does patient selection matter? Neurology, 92(2):65-66.

DOI: https://doi.org/10.1212/WNL.0000000000006719 


\section{ECG monitoring after acute ischemic stroke}

\section{Does patient selection matter?}

Mira Katan, MD, MS, and Steven A. Lubitz, MD, MPH

Neurology ${ }^{\circledR}$ 2019;92:65-66. doi:10.1212/WNL.0000000000006719

To prevent stroke recurrence, we treat patients based on the presumed underlying etiology; however, in clinical practice, the underlying mechanism remains undetermined in up to $30 \%$ of patients. ${ }^{1}$ Atrial fibrillation (AF), a known and frequent culprit for cardioembolic stroke, can be transient and not present at the time of evaluation following a stroke. Treatment differs for patients who have strokes caused by AF because of the high risk of recurrent stroke with AF and the high degree of effectiveness of oral anticoagulants to reduce cardioembolic stroke risk. Several guidelines recommend a minimum of 24 to 48 hours of Holter monitoring in all patients with stroke to identify AF as the underlying source of stroke. ${ }^{2}$ Previous studies found that Holter ECG monitoring (24-72 hours) detects paroxysmal AF in approximately $5 \%$ of patients with stroke, and longer duration ECG monitoring detects AF in an additional 5\% to $30 \%$ of patients depending on the type and duration of monitoring. ${ }^{2-4}$

Despite this increasing evidence in support of the effectiveness of prolonged ECG monitoring for the improved detection of $\mathrm{AF}$, the implementation rate in routine clinical practice remains low. For example, among 17,398 consecutive patients with stroke from the Ontario Stroke Registry (2003-2013), only 30.6\% of patients received at least 24 hours of Holter monitoring 30 days after stroke and less than $1 \%$ of patients received monitoring beyond 48 hours. ${ }^{2}$ Results from surveys collected worldwide show very similar results: less than $20 \%$ of patients with stroke receive more than 48 hours of Holter ECG. ${ }^{5}$ Reasons for the lack of implementation of cardiac rhythm monitoring include logistical challenges, patient adherence, and costs, among others.

Many questions remain. Which patient will likely benefit from long-term ECG monitoring? Should all cryptogenic stroke patients with presumed embolic source of stroke undergo longterm ECG monitoring? Would an alternative approach in which monitoring is allocated to patients at high risk of AF be more cost-effective? Moreover, what should we do about patients with other presumed causes of stroke? For example, should a patient with a clear large vessel stroke (e.g., ipsilateral high-grade carotid stenosis), or a lacunar stroke, also be monitored for longer than 24 hours, since small or large vessel atherosclerosis does not protect them from AF and subsequent strokes due to $\mathrm{AF}$ ?

In this issue of Neurology ${ }^{\circledast}$, Uphaus et al. ${ }^{6}$ derived and validated a simple prediction score for AF in ischemic stroke patients without a history of AF. They used data from 3 different studies (total $n=1,556)$, consisting of stroke $(78 \%)$ or TIA $(22 \%)$ patients with at least 72 hours of ECG Holter monitoring. They identified 77 cases of AF (5\%). They defined AF as $>30$ seconds of arrhythmia within 72 hours of the stroke. They entered and retained candidate variables using logistic regression with backward selection. The authors derived a score they named AS5F (Age: 0.76 points/year, Stroke Severity NIHSS $\leq 5=9$ points, NIHSS $>5=21$ points; to Find $\mathrm{AF}$ ). The authors report a high-risk group of patients (a score above 67.5), which corresponded to a $5.2 \%$ risk and a number needed to screen below 20 to observe one case of AF within 72 hours.

The proposed AS5F score has several strengths, including its simplicity and reported ability to discriminate individuals at high risk of developing $\mathrm{AF}$ also in patients without a presumed

\author{
Correspondence \\ Dr. Katan \\ mira.katan@usz.ch
}

RELATED ARTICLE

Development and

validation of a score to detect paroxysmal atrial fibrillation after stroke

Page 70 
cardioembolic source (e.g., small vessel strokes). We commend the authors for bringing a systematic statistical approach to addressing a problem of clinical relevance.

Several limitations warrant mentioning. First, this was a small sample. The derivation set included only 44 cases of $\mathrm{AF}$ and the validation set only 33 cases. The small sample size can bias the weights used in the score and lead to inaccurate probability estimates. Second, many other validated predictors of AF exist, which were not retained in the current model (probably because of the small sample size and limited power). These predictors include race, routinely ascertained clinical risk factors, ${ }^{7}$ as well as other measures such as $\mathrm{P}$ wave terminal force in V1 on the initial routine 12 -lead $\mathrm{ECG}^{8}$ or natriuretic peptides ${ }^{9}$ measured on admission with the first blood draw. These measures may substantially increase the predictive accuracy of the score and should therefore be assessed in future studies. Third, with the increasing availability of technology to monitor cardiac rhythms, questions are likely to be centered on appropriate allocation of monitors for long-term AF detection, rather than short-term detection within 72 hours. $^{4,10}$

In the context of the recently published negative results of the Navigate ESUS (Embolic Stroke of Undetermined Source) trial, ${ }^{11}$ there is much we still do not understand about the interplay between the presumed mechanism of stroke and AF risk. Future studies are warranted to determine whether an approach of identifying high AF-risk patient groups for underlying AF or even atrial cardiopathy, ${ }^{12}$ to guide the utilization of cardiac rhythm monitoring or anticoagulation, is effective.

\section{Study funding}

No targeted funding reported.

\section{Disclosure}

M. Katan has received funding from BRAHMS Thermo Fisher, the Swiss National Science Foundation (PZ00P3 142422), the Spital-Pool of the University Hospital of Zurich, the Swiss Heart Foundation, and the Leducq Foundation; and serves on the editorial board of Stroke. S. Lubitz has served on scientific advisory boards for St. Jude Medical/Abbott and Bristol-Myers Squibb; is supported by NIH grant 1R01HL139731 and American Heart Association grant 18SFRN34250007; receives research support from the Doris Duke Charitable Foundation, Bristol-Myers Squibb, Pfizer, Bayer HealthCare, Biotronik, and Boehringer Ingelheim; and has consulted for Abbott, Quest Diagnostics, and BristolMyers Squibb. Go to Neurology.org/N for full disclosures.

\section{References}

1. Hart RG, Diener HC, Coutts SB, et al. Embolic strokes of undetermined source: the case for a new clinical construct. Lancet Neurol 2014;13:429-438.

2. Edwards JD, Kapral MK, Fang J, Saposnik G, Gladstone DJ; Investigators of the Registry of the Canadian Stroke Network. Underutilization of ambulatory ECG monitoring after stroke and transient ischemic attack: missed opportunities for atrial fibrillation detection. Stroke 2016;47:1982-1989.

3. Gladstone DJ, Spring M, Dorian P, et al. Atrial fibrillation in patients with cryptogenic stroke. N Engl J Med 2014;370:2467-2477.

4. Sanna T, Diener HC, Passman RS, et al. Cryptogenic stroke and underlying atrial fibrillation. N Engl J Med 2014;370:2478-2486.

5. Giruparajah M, Bosch J, Vanassche T, et al. Global survey of the diagnostic evaluation and management of cryptogenic ischemic stroke. Int J Stroke 2015;10:1031-1036.

6. Uphaus T, Weber-Krüger M, Grond M, et al. Development and validation of a score to detect paroxysmal atrial fibrillation after stroke. Neurology 2019;92:e115-e124.

7. Alonso A, Krijthe BP, Aspelund T, et al. Simple risk model predicts incidence of atrial fibrillation in a racially and geographically diverse population: the CHARGE-AF consortium. J Am Heart Assoc 2013;2:e000102.

8. He J, Tse G, Korantzopoulos P, et al. P-wave indices and risk of ischemic stroke: a systematic review and meta-analysis. Stroke 2017;48:2066-2072.

9. De Marchis GM, Schneider J, Weck A, et al. Midregional proatrial natriuretic peptide improves risk stratification after ischemic stroke. Neurology 2018;90:e455-e465.

10. Treskes RW, Gielen W, Wermer MJ, et al. Mobile Phones in Cryptogenic Stroke Patients Bringing Single Lead ECGs for Atrial Fibrillation Detection (MOBILE-AF): study protocol for a randomised controlled trial. Trials 2017;18:402.

11. Hart RG, Sharma M, Mundl H, et al. Rivaroxaban for stroke prevention after embolic stroke of undetermined source. N Engl J Med 2018;378:2191-2201.

12. Kamel H, Okin PM, Longstreth WT Jr, Elkind MS, Soliman EZ. Atrial cardiopathy: a broadened concept of left atrial thromboembolism beyond atrial fibrillation. Future Cardiol 2015;11:323-331. 


\section{Neurology}

\section{ECG monitoring after acute ischemic stroke: Does patient selection matter? Mira Katan and Steven A. Lubitz}

Neurology 2019;92;65-66 Published Online before print December 7, 2018

DOI 10.1212/WNL.0000000000006719

This information is current as of December 7, 2018

\section{Updated Information \&} Services

References

Subspecialty Collections

Permissions \& Licensing

Reprints including high resolution figures, can be found at: http://n.neurology.org/content/92/2/65.full

This article cites 12 articles, 5 of which you can access for free at: http://n.neurology.org/content/92/2/65.full\#ref-list-1

This article, along with others on similar topics, appears in the following collection(s):

All Cerebrovascular disease/Stroke

http://n.neurology.org/cgi/collection/all_cerebrovascular_disease_strok e

All Clinical Neurology

http://n.neurology.org/cgi/collection/all_clinical_neurology

Cardiac

http://n.neurology.org/cgi/collection/cardiac

Infarction

http://n.neurology.org/cgi/collection/infarction

Stroke prevention

http://n.neurology.org/cgi/collection/stroke_prevention

Information about reproducing this article in parts (figures,tables) or in its entirety can be found online at:

http://www.neurology.org/about/about_the_journal\#permissions

Information about ordering reprints can be found online:

http://n.neurology.org/subscribers/advertise

Neurology ${ }^{\circledR}$ is the official journal of the American Academy of Neurology. Published continuously since 1951, it is now a weekly with 48 issues per year. Copyright () 2018 American Academy of Neurology. All rights reserved. Print ISSN: 0028-3878. Online ISSN: 1526-632X.

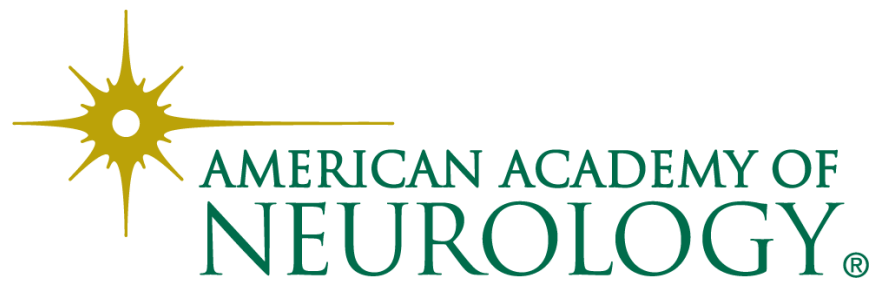

